\title{
Alternative reference evapotranspiration methods for the main climate types of the state of Paraná, Brazil
}

\author{
Bruno César Gurski(1), Daniela Jerszurki(2) and Jorge Luiz Moretti de Souza ${ }^{(1)}$
}

(1)Universidade Federal do Paraná, Rua dos Funcionários, no 1.540, CEP 80035-050 Curitiba, PR, Brazil. E-mail: brunogurski@ufpr.br,
jmoretti@ufpr.br (2)Jacob Blaustein Institutes for Desert Research, Ben-Gurion University of the Negev, Sede Boqer Campus, 84990,
Negev, Israel. E-mail: djerszurki@ufpr.br

Abstract - The objective of this work was to define the best alternative methods for estimating the reference evapotranspiration (ETo) in the main climatic types (Cfa and Cfb) of the state of Paraná, Brazil. The methods tested were Budyko, Camargo, Hargreaves-Samani, Linacre, and Thornthwaite, which were compared to the ETo calculated with the Penman-Monteith ASCE $\left(\mathrm{ETo}_{\mathrm{PM}}\right)$ method, between 1986 and 2015, in eight meteorological stations. The performance of the alternative methods was obtained from the coefficient of determination $\left(\mathrm{R}^{2}\right)$, index "d" of agreement, index "c" of performance, and root mean square error (RMSE). The Hargreaves-Samani method has a better performance in estimating the ETo for the main climatic types in the state of Paraná. The Camargo method allows smaller errors between the standard values of ETo, obtained with the Penman-Monteith method, and the estimated values. The methods of Thornthwaite, Linacre, and Budyko are not adequate to estimate the ETo in any climatic type of the state of Paraná, Brazil.

Index terms: climate variability, irrigation management, missing climate data, Penman Monteith, simplified models, water balance.

\section{Métodos alternativos de evapotranspiração de referência para os principais tipos climáticos do Paraná}

Resumo - O objetivo deste trabalho foi definir os melhores métodos alternativos de estimativa de evapotranspiração de referência (ETo), para os principais tipos climáticos (Cfa e Cfb) do Estado do Paraná. Foram testados os métodos de Budyko, Camargo, Hargreaves-Samani, Linacre e Thornthwaite, os quais foram comparados com a ETo calculada com o método de Penman-Monteith ASCE (ETo $\left.{ }_{\mathrm{PM}}\right)$, entre 1986 e 2015, em oito estações meteorológicas. O desempenho dos métodos alternativos foi obtido por meio do coeficiente de determinação $\left(\mathrm{R}^{2}\right)$, do índice "d" de concordância, do índice "c" de desempenho e da raiz quadrada do erro médio (RMSE). O método de Hargreaves-Samani tem melhor desempenho na estimativa da evapotranspiração de referência para os principais tipos climáticos do Paraná. O método de Camargo possibilita menores erros entre valores padrão de ETo, obtidos com o método Penman-Monteith, e os valores estimados. Os métodos de Thornthwaite, Linacre e Budyko não são adequados para estimar a ETo em nenhum tipo climático do Estado do Paraná.

Termos para indexação: variabilidade climática, manejo da irrigação, dados climáticos faltantes, Penman Monteith, modelos simplificados, balanço hídrico.

\section{Introduction}

The reference evapotranspiration (ETo) is one of the most important hydrological variables for interpretation of agricultural water balances and irrigation management (Yan et al., 2012). The ETo can be measured directly from lysimeters and evapotranspirometers, or estimated from theoretical methods based on climate variables such as air temperature and solar radiation (Allen et al., 1998; Todorovic et al., 2013; Pereira et al., 2015). Due to the high cost of direct measurement, however, the estimated ETo has been used with satisfactory performance around the world (Pandey et al., 2016).

Traditionally, the combined method of PenmanMonteith, parameterized by the Food and Agriculture Organization of the United Nations (Allen et al., 1998) and by the American Society of Civil Engineers (Allen et al., 2005), is recognized as the standard method for estimating ETo (Chauhan \& Shrivastava, 2009). However, the lack of many variables needed for the

Pesq. agropec. bras., Brasília, v.53, n.9, p.1003-1010, Sept. 2018 DOI: 10.1590/S0100-204X2018000900003 
calculation has been limiting the use of this method in Brazil and in other countries with economical or technical restraints for the installation and maintenance of meteorological stations. This situation results in incomplete or inconsistent data series (Souza et al., 2014; Alencar et al., 2015), even considering the different climate database of meteorological data around the world, as World Climate Database (Hijmans et al., 2005).

Therefore, alternative methods have been developed to estimate ETo with a small number of climate variables of easy measurement (Chauhan \& Shrivastava, 2009), with the following examples over the last 50 years: Penman (1948), Thornthwaite (1948), Campbell (1973), Budyko (1974), Linacre (1977), and Hargreaves \& Samani (1985). Nonetheless, it is common for the literature to report only the comparative performance of these methods to the Penman-Monteith standard (Borges \& Mendiondo, 2007; Oliveira et al., 2008; Trajkovic \& Kolakovic, 2009), with few studies analyzing the adjustment of the alternative methods to different climate types (Todorovic et al., 2013), despite the fact that several authors had clearly demonstrated the influence of it on ETo estimation as well as on the performance of the alternative methods (Trajkovic \& Kolakovic, 2009; Pandey et al., 2016). Due to climate variability observed in the state of Paraná, Brazil, studies of this nature are important for the region, as they would allow the identification of trends and limitations of the alternative methods, as well as the choice of the best method for each climate type.

The objective of this work was to define the best alternative methods for estimating the reference evapotranspiration (ETo) in the main climatic types $(\mathrm{Cfa}$ and $\mathrm{Cfb})$ of the state of Paraná, Brazil.

\section{Materials and Methods}

Analyses were carried out for a set of 30 years of daily historical data (January 1986 to December 2015) of maximum, minimum, and average air temperatures $\left({ }^{\circ} \mathrm{C}\right)$, relative humidity $(\%)$, extraterrestrial radiation

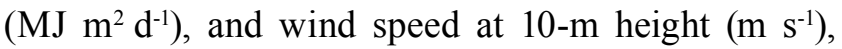
available at the Brazilian National Institute of Meteorology (Inmet, 2016). These data were obtained from eight automatic weather stations located in the state of Paraná (Figure 1), under the climate types Cfa and $\mathrm{Cfb}$, which represent 61.7 and $37 \%$ of the state area, respectively. According to Köppen (1936), the
Cfa climate is characterized as subtropical, with hot summers and an annual mean temperature between 16 and $18^{\circ} \mathrm{C}$, while $\mathrm{Cfb}$ is a temperate climate, with mild summers, no dry season, and average precipitation of 1,500 $\mathrm{mm}_{\text {year }}{ }^{-1}$ (Alvares et al., 2013).

The meteorological stations used (Figure 1) were the only ones in the state with sufficient representative data to compare the alternative methods Budyko (1974), Camargo (1971), Hargreaves \& Samani (1985), Linacre (1977) and Thornthwaite (1948) with the Penman-Monteith (Allen et al., 2005) standard.

Daily reference evapotranspiration $\left(\mathrm{ETO}_{\mathrm{PM}}\right)$ was estimated with Penman-Monteith method, parameterized by American Society of Civil Engineers (Allen at al., 2005).

$$
\mathrm{ETo}_{\mathrm{PM}}=\frac{0.408 \times \Delta \times\left(\mathrm{R}_{\mathrm{n}}-\mathrm{G}\right)+\gamma_{\mathrm{psy}} \times \frac{\mathrm{C}_{\mathrm{n}}}{(\mathrm{T}+273)} \times \mathrm{u}_{2} \times\left(\mathrm{e}_{\mathrm{s}}-\mathrm{e}_{\mathrm{a}}\right)}{\Delta+\gamma_{\mathrm{psy}} \times\left(1+\mathrm{C}_{\mathrm{d}} \times \mathrm{u}_{2}\right)}
$$

where $\mathrm{ETo}_{\mathrm{PM}}$ is the reference evapotranspiration $\left(\mathrm{mm} \mathrm{d}^{-1}\right) ; \Delta$, the slope of the saturated water-vapourpressure curve $\left(\mathrm{kPa}^{\circ} \mathrm{C}^{-1}\right) ; \mathrm{R}_{\mathrm{n}}$, the net radiation at the crop surface $\left(\mathrm{MJ} \mathrm{m}^{-2} \mathrm{~d}^{-1}\right) ; \mathrm{G}$, the soil heat flux (MJ $\left.\mathrm{m}^{-2} \mathrm{~d}^{-1}\right) ; \gamma_{\mathrm{psy}}$, the psychrometric constant $\left(\mathrm{kPa}^{\circ} \mathrm{C}^{-1}\right) ; \mathrm{T}$, the daily average air temperature $\left({ }^{\circ} \mathrm{C}\right)$; $\mathrm{u}_{2}$, the wind speed at 2-m height $\left(\mathrm{m} \mathrm{s}^{-1}\right) ; \mathrm{e}_{\mathrm{s}}$, the saturation vapor pressure $(\mathrm{kPa}) ; \mathrm{e}_{\mathrm{a}}$, the actual vapor pressure $(\mathrm{kPa}) ; \mathrm{C}_{\mathrm{n}}$, the constant related to the reference cover type and to the calculation time step, considered equal to 900 for grass (dimensionless); and $\mathrm{C}_{\mathrm{d}}$, a constant related to the reference cover type and calculation time step, considered equal to 0.34 for grass (dimensionless).

Daily vapor pressure deficit was estimated by the difference between saturated and actual vapor pressure $\left(e_{s}-e_{a}\right)$. Saturated vapor pressure was calculated using air temperature based on the Tetens formula. Actual vapor pressure was obtained by saturated vapor pressure multiplied by fractional humidity. Daily net radiation $(\mathrm{Rn})$ was estimated by the difference between net longwave and shortwave radiation. The net longwave radiation (NLR) was obtained by the relative shortwave radiation (Rs/ Rso), air temperature, and actual vapor pressure. The net shortwave radiation (NSR) was obtained by solar radiation (Rs), which was estimated by the relation between extraterrestrial radiation ( $\mathrm{Ra}$ ) and relative sunshine duration $(\mathrm{n} / \mathrm{N})$ (Pereira et al., 2015). The soil heat flux $(\mathrm{G})$ was calculated using air temperature (Pereira et al., 1997). The wind speed measurements 
were transformed to wind speed at 2-m height by the wind profile relationship (Allen et al., 1998).

The Budyko (1974) method uses the following expression: $\mathrm{ETo}_{\mathrm{B}} \mathrm{i}=0.20 \times \mathrm{T}_{\mathrm{i}}$, where $\mathrm{ETo}_{\mathrm{B}} \mathrm{i}$ is the reference evapotranspiration obtained using the Budyko (1974) method for the i-th day ( $\left.\mathrm{mm} \mathrm{day}^{-1}\right)$; and $\mathrm{T}$ is the daily average air temperature in the i-th day $\left({ }^{\circ} \mathrm{C}\right)$. For the Camargo (1971) method, the expression $\mathrm{ETo}_{\mathrm{Ci}}=\mathrm{Qo}_{\mathrm{i}} \times \mathrm{F} \times \mathrm{T}_{\mathrm{i}}$ was used, where: $\mathrm{ETo}_{\mathrm{Ci}}$ is the reference evapotranspiration by Camargo (1971) method, for the i-th day $\left(\mathrm{mm} \mathrm{day}^{-1}\right)$; $\mathrm{Qo}_{i}$, the radiation of the i-th day, calculated as evaporation $\left(\mathrm{mm} \mathrm{day}^{-1}\right) ; \mathrm{F}$, the adjustment factor according to the site; and $\mathrm{T}$, the daily average air temperature $\left({ }^{\circ} \mathrm{C}\right)$.

The extraterrestrial radiation of the $\mathrm{i}$-th day was transformed in equivalent evaporation $\left(\mathrm{Qo}_{\mathrm{i}}-\mathrm{mm} \mathrm{day}^{-1}\right)$ from the latent heat of evaporation $\left(\lambda=2.45 \mathrm{MJ} \mathrm{kg}^{-1}\right)$ :

$$
\mathrm{Qo}_{\mathrm{i}\left(\mathrm{mm} \mathrm{day}^{-1}\right)}=\mathrm{R}_{\mathrm{a}} / 2.45
$$

where $R_{a}$ is the extraterrestrial radiation of the $i$-th day $\left(\mathrm{MJ} \mathrm{m}^{-2} \mathrm{day}^{-1}\right)$. The extraterrestrial radiation (Ra) was obtained according to Allen et al. (1998).

The Hargreaves \& Samani (1985) method was calculated with the expression: $\mathrm{ETo}_{\mathrm{HS}} \mathrm{i}=0.0023 \times \mathrm{Qo}_{\mathrm{i}}$ $\times\left(\mathrm{T}_{\mathrm{i}}+17.8\right) \times\left(\mathrm{T}_{\text {MAX }}-\mathrm{T}_{\text {MIN }}\right)^{0.5}$, where $\mathrm{ETo}_{\mathrm{HS}} \mathrm{i}$ is the reference evapotranspiration by Hargreaves \& Samani (1985) method for the i-th day (mm day $\left.{ }^{-1}\right) ; \mathrm{Qo}_{\mathrm{i}}$, the extraterrestrial radiation of the i-th day, calculated as evaporation $\left(\mathrm{mm} \mathrm{day}{ }^{-1}\right) ; \mathrm{T}_{\mathrm{i}}$, the daily average air temperature $\left({ }^{\circ} \mathrm{C}\right) ; \mathrm{T}_{\mathrm{MAX}}$, the maximum air temperature in the i-th day $\left({ }^{\circ} \mathrm{C}\right)$; and $\mathrm{T}_{\mathrm{MIN}}$, the minimum air temperature in the $\mathrm{i}$-th day $\left({ }^{\circ} \mathrm{C}\right)$.

The transformation of the extraterrestrial radiation of the $\mathrm{i}$-th day in equivalent of evaporation $\left(\mathrm{Qo}_{\mathrm{i}}-\mathrm{mm}\right.$ day $\left.^{-1}\right)$ was done from the latent heat of evaporation $(\lambda=$ $2.45 \mathrm{MJ} \mathrm{kg}^{-1}$ ), as proposed by Camargo (1971).

The Linacre (1977) method was calculated with the expression:

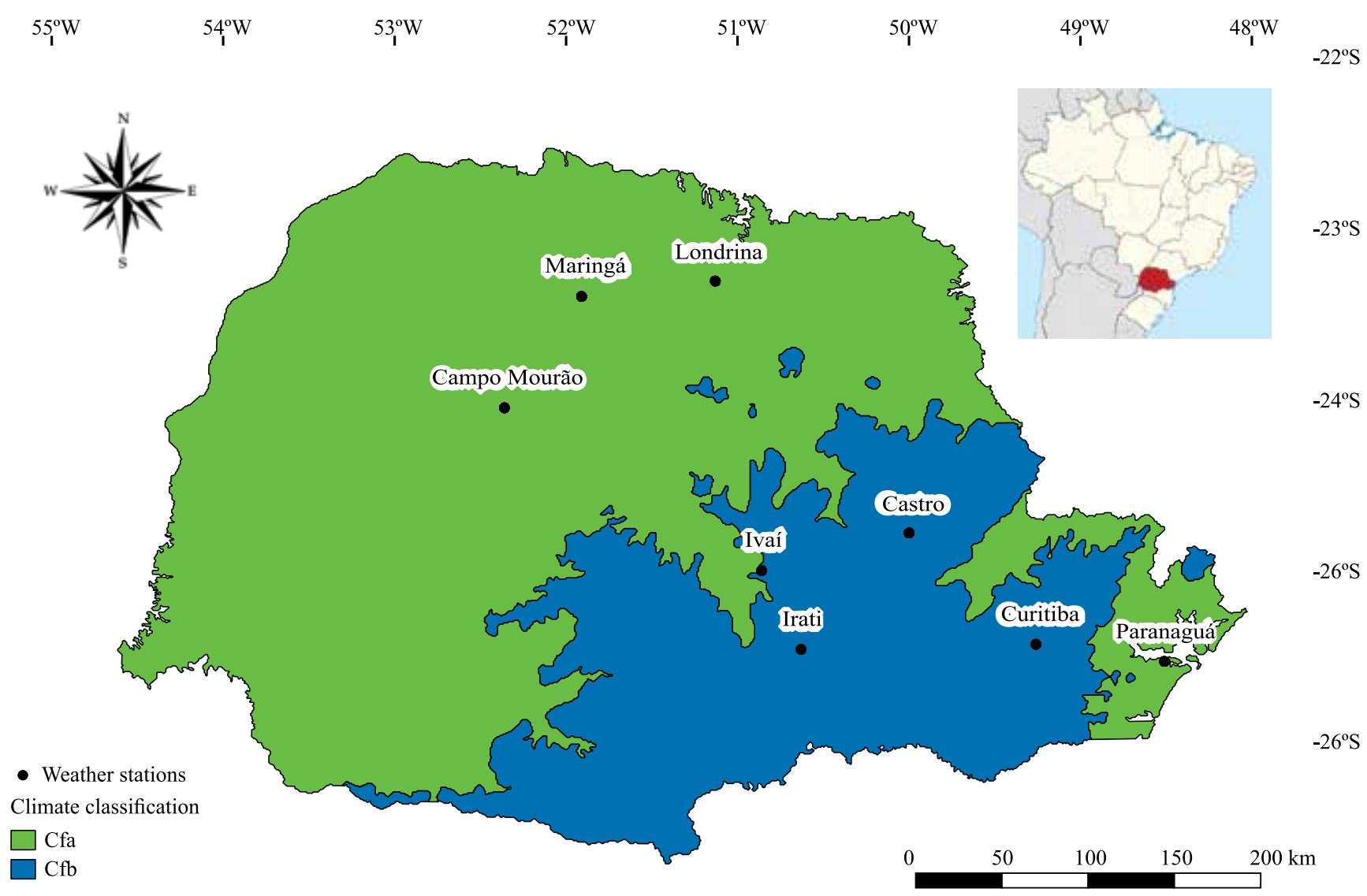

Figure 1. Location of weather stations in the state of Paraná, Brazil, in the main climate types of the state. Source: Adapted from INMET (2016). 


$$
\mathrm{ETo}_{\mathrm{Li}}=\frac{700 \times \frac{\mathrm{T}+0.006 \mathrm{z}}{100-\varphi}+15\left(\mathrm{~T}-\mathrm{Td}_{\mathrm{i}}\right)}{80-\mathrm{T}}
$$

where $\mathrm{ETo}_{\mathrm{L}} \mathrm{i}$ is the reference evapotranspiration by Linacre method for the i-th day $\left(\mathrm{mm} \mathrm{day}^{-1}\right)$; $\mathrm{T}$, the daily average air temperature $\left({ }^{\circ} \mathrm{C}\right) ; \mathrm{z}$, the local altitude $(\mathrm{m})$; $\phi$, the site latitude (degrees); and $\mathrm{Td}_{\mathrm{i}}$, the dew point temperature in the i-th day $\left({ }^{\circ} \mathrm{C}\right)$.

The Thornthwaite (1948) method uses daily average air temperature $(\mathrm{T})$, considering a month of 30 days and 12 hours of photoperiod:

$$
\begin{aligned}
& \mathrm{ETo}_{\mathrm{Hi}}=\frac{\mathrm{N}_{\mathrm{i}}}{12} \times \frac{1}{30} \times 16 \times\left(\frac{10 \times \mathrm{T}}{\mathrm{I}}\right)^{\mathrm{a}}, \text { for }: \mathrm{T}>0^{\circ} \mathrm{C} \\
& \mathrm{a}=6.75 \times 10^{-7} \times \mathrm{I}^{3}-7.71 \times 10^{-5} \times \mathrm{I}^{2}+1.7912 \times 10^{-2} \times \mathrm{I}+0.49239 \\
& \mathrm{I}=\sum_{\mathrm{i}=1}^{12}\left(0.2 \times \mathrm{T}_{\mathrm{a}}\right)^{1.514}, \text { for }: \mathrm{T}_{\mathrm{a}}>0^{\circ} \mathrm{C}
\end{aligned}
$$

where $\mathrm{ETo}_{\mathrm{TH}}$ is the reference evapotranspiration by Thornthwaite (1948) method for the i-th day $\left(\mathrm{mm} \mathrm{day}^{-1}\right)$; $\mathrm{N}_{\mathrm{i}}$, the photoperiod in i-th day (h); T, the daily average air temperature $\left({ }^{\circ} \mathrm{C}\right)$; a, the cubic function of the heat index (I) of the region (dimensionless); I, the heat index in the region (dimensionless); and $\mathrm{T}_{\mathrm{a}}$, the average normal temperature of the m-th month of the year $\left({ }^{\circ} \mathrm{C}\right)$.

The performance of the alternative methods was evaluated according to the adjustment of the estimated ETo to standard ETo obtained with the Penman-Monteith (Allen at al., 2005) method, using: linear regression analysis $\left(\mathrm{R}^{2}\right)$, agreement index "d" (Willmott et al., 1985), performance index "c" (Camargo \& Sentelhas, 1997) (Table 1), and root mean square error (RMSE), obtained with the following equations:

Table 1. Interpretation criteria of the alternative methods performance, according to $\mathrm{c}$ index proposed by Camargo \& Sentelhas (1997).

\begin{tabular}{cc}
\hline C value & Performance \\
\hline $\mathrm{c}>0.85$ & Great \\
$0.85 \leq \mathrm{c}<0.75$ & Very good \\
$0.75 \leq \mathrm{c}<0.65$ & Good \\
$0.65 \leq \mathrm{c}<0.60$ & Average \\
$0.60 \leq \mathrm{c}<0.50$ & Tolerable \\
$0.50 \leq \mathrm{c}<0.40$ & Bad \\
$\mathrm{c} \leq 0.40$ & Very Bad \\
\hline
\end{tabular}

$$
\begin{aligned}
& \mathrm{d}=1-\left[\frac{\sum_{\mathrm{i}=1}^{\mathrm{n}}\left(\mathrm{E}_{\mathrm{i}}-\mathrm{O}_{\mathrm{i}}\right)^{2}}{\sum_{\mathrm{i}=1}^{\mathrm{n}}\left(\left|\mathrm{E}_{\mathrm{i}}-\overline{\mathrm{O}}_{\mathrm{i}}\right|+\left|\mathrm{O}_{\mathrm{i}}-\overline{\mathrm{O}}_{\mathrm{i}}\right|\right)^{2}}\right] \\
& \mathrm{c}=|\mathrm{R} \times \mathrm{d}| \\
& \mathrm{RMSE}=\sqrt{\frac{1}{\mathrm{n}} \times \sum_{\mathrm{i}=1}^{\mathrm{n}}\left(\mathrm{E}_{\mathrm{i}}-\mathrm{O}_{\mathrm{i}}\right)^{2}}
\end{aligned}
$$

where $\mathrm{d}$ is the agreement index of Willmott et al. (1985) (dimensionless); $\mathrm{E}_{\mathrm{i}}$, the ETo estimated by alternative methods in the i-th day $\left(\mathrm{mm} \mathrm{day}^{-1}\right) ; \mathrm{O}_{\mathrm{i}}$, the ETo estimated by Penman-Monteith method in the i-th day $\left(\mathrm{mm} \mathrm{day}{ }^{-1}\right) ; \bar{O}_{i}$, the mean of the ETo estimated by Penman-Monteith method ( $\left.\mathrm{mm} \mathrm{day}{ }^{-1}\right) ; \mathrm{n}$, the number of observations (dimensionless); c, the performance index of Camargo \& Sentelhas (1997) (dimensionless); $r$, the correlation coefficient (dimensionless); and RMSE, the root mean square error $\left(\mathrm{mm} \mathrm{day}^{-1}\right)$.

\section{Results and Discussion}

The climate types had significant effect on the performance of the alternative methods (Tables 2 and 3 ), as it was also reported in Trajkovic \& Kolakovic (2009) and Pandey et al. (2016). In general, the Hargreaves-Samani and Camargo methods showed the best performances for both $\mathrm{Cfa}$ and $\mathrm{Cfb}$ climates, and the Camargo method had the smallest errors (RMSE). Syperreck et al. (2008) evaluated alternative methods in a single locality with Cfa climate in Paraná, and observed that the Hargreaves-Samani method provided the best results $(\mathrm{r}=0.86, \mathrm{~d}=0.85$, and $\mathrm{c}=$ 0.73), followed by the methods of Thornthwaite and Camargo. Camargo \& Sentelhas (1997), comparing 20 alternative methods of estimation of ETo with measurements in evapotranspirometers in the state of São Paulo (Cfa), Brazil, reported better estimates for the methods of Camargo and Thornthwaite.

The use of solar radiation in alternative methods is acknowledged as a sound procedure for estimating ETo in the literature, providing good results (Yoder et al., 2005; Irmak et al., 2006). The Hargreaves-Samani and Camargo methods use it as an input variable (Yan et al., 2012), which may have contributed to the best estimates of ETo obtained with them. According to Hupet \& Vanclooster (2001), solar radiation has a great influence on the ETo in cold and humid climates, due to the lower magnitude and influence of the other 
Table 2. Parameters used to compare the performance of the alternative methods for determination of reference evapotranspiration (ETo), in relation to Penman-Monteith standard method $\left(\mathrm{ETo}_{\mathrm{PM}}\right)$, for the climate type Cfa, in state of Paraná, Brazil ${ }^{(1)}$.

\begin{tabular}{|c|c|c|c|c|c|c|}
\hline Parameter & Penman-Monteith & Budyko & Camargo & Hargreaves \& Samani & Linacre & Thornthwaite \\
\hline & \multicolumn{6}{|c|}{ Campo Mourão } \\
\hline Average & 3.14 & 4.07 & 2.84 & 4.08 & 2.69 & 1.50 \\
\hline Linear coefficient & & -1.37 & 0.45 & -0.24 & -0.25 & 1.56 \\
\hline Angular coefficient & & 1.11 & 0.95 & 0.83 & 1.26 & 1.05 \\
\hline $\mathrm{R}^{2}$ & & 0.45 & 0.57 & 0.78 & 0.63 & 0.77 \\
\hline r & & 0.67 & 0.75 & 0.88 & 0.79 & 0.88 \\
\hline Index “d" & & 0.88 & 0.93 & 0.92 & 0.92 & 0.76 \\
\hline Index “c" & & 0.59 & 0.70 & 0.82 & 0.72 & 0.66 \\
\hline Performance & & Tolerable & Good & Very good & Good & Good \\
\hline \multirow[t]{2}{*}{ RMSE } & & 1.35 & 0.91 & 1.15 & 0.94 & 1.76 \\
\hline & \multicolumn{6}{|c|}{ Londrina } \\
\hline Average & 2.23 & 4.30 & 3.00 & 4.17 & 3.33 & 1.82 \\
\hline Linear coefficient & & -1.33 & 0.27 & -0.16 & 0.56 & 1.71 \\
\hline Angular coefficient & & 0.88 & 0.73 & 0.62 & 0.65 & 0.82 \\
\hline $\mathrm{R}^{2}$ & & 0.26 & 0.35 & 0.43 & 0.29 & 0.64 \\
\hline $\mathrm{r}$ & & 0.51 & 0.59 & 0.65 & 0.54 & 0.80 \\
\hline Index “d” & & 0.74 & 0.63 & 0.60 & 0.66 & 0.62 \\
\hline Index “c” & & 0.38 & 0.37 & 0.39 & 0.35 & 0.50 \\
\hline Performance & & Very bad & Very bad & Very bad & Very bad & $\mathrm{Bad}$ \\
\hline \multirow[t]{2}{*}{ RMSE } & & 2.17 & 1.23 & 2.06 & 1.33 & 1.57 \\
\hline & \multicolumn{6}{|c|}{ Maringá } \\
\hline Average & 3.06 & 4.44 & 3.10 & 4.05 & 3.84 & 2.01 \\
\hline Linear coefficient & & -1.63 & 0.44 & -0.01 & 0.86 & 1.92 \\
\hline Angular coefficient & & 1.10 & 0.91 & 0.81 & 0.63 & 0.77 \\
\hline $\mathrm{R}^{2}$ & & 0.43 & 0.56 & 0.70 & 0.40 & 0.65 \\
\hline r & & 0.66 & 0.75 & 0.84 & 0.63 & 0.80 \\
\hline Index “d” & & 0.88 & 0.69 & 0.72 & 0.68 & 0.62 \\
\hline Index “c” & & 0.58 & 0.52 & 0.60 & 0.43 & 0.50 \\
\hline Performance & & Tolerable & Tolerable & Tolerable & $\mathrm{Bad}$ & $\mathrm{Bad}$ \\
\hline \multirow[t]{2}{*}{ RMSE } & & 1.52 & 0.86 & 1.08 & 1.24 & 1.65 \\
\hline & \multicolumn{6}{|c|}{ Paranaguá } \\
\hline Average & 1.95 & 4.32 & 3.00 & 3.41 & 2.45 & 1.31 \\
\hline Linear coefficient & & -1.63 & 0.16 & 0.07 & -0.10 & 1.62 \\
\hline Angular coefficient & & 0.90 & 0.70 & 0.65 & 0.96 & 0.87 \\
\hline $\mathrm{R}^{2}$ & & 0.41 & 0.53 & 0.60 & 0.43 & 0.67 \\
\hline $\mathrm{r}$ & & 0.64 & 0.73 & 0.78 & 0.66 & 0.82 \\
\hline Index “d” & & 0.74 & 0.76 & 0.74 & 0.74 & 0.58 \\
\hline Index “c” & & 0.47 & 0.55 & 0.58 & 0.49 & 0.47 \\
\hline Performance & & $\mathrm{Bad}$ & Tolerable & Tolerable & $\mathrm{Bad}$ & $\mathrm{Bad}$ \\
\hline RMSE & & 2.20 & 1.07 & 1.39 & 0.80 & 1.60 \\
\hline
\end{tabular}

(1)Data from 1986 to 2015. 
Table 3. Parameters used to compare the performance of the alternative methods for determination of reference evapotranspiration (ETo), in relation to Penman-Monteith standard method $\left(\mathrm{ETo}_{\mathrm{PM}}\right)$, for the climate type $\mathrm{Cfb}$, in state of Paraná, Brazil ${ }^{(1)}$.

\begin{tabular}{|c|c|c|c|c|c|c|}
\hline Parameter & Penman-Monteith & Budyko & Camargo & Hargreaves \& Samani & Linacre & Thornthwaite \\
\hline & \multicolumn{6}{|c|}{ Castro } \\
\hline Average & 2.86 & 3.41 & 2.36 & 3.63 & 2.27 & 0.93 \\
\hline Linear coefficient & & -0.33 & 0.73 & 0.04 & 0.09 & 2.15 \\
\hline Angular coefficient & & 0.95 & 0.92 & 0.79 & 1.24 & 1.11 \\
\hline $\mathrm{R}^{2}$ & & 0.32 & 0.45 & 0.58 & 0.42 & 0.32 \\
\hline r & & 0.56 & 0.67 & 0.76 & 0.65 & 0.57 \\
\hline Index “d” & & 0.76 & 0.72 & 0.78 & 0.68 & 0.51 \\
\hline Index “c” & & 0.43 & 0.48 & 0.59 & 0.44 & 0.29 \\
\hline Performance & & $\mathrm{Bad}$ & $\mathrm{Bad}$ & Tolerable & $\mathrm{Bad}$ & Very bad \\
\hline \multirow[t]{2}{*}{ RMSE } & & 1.21 & 1.13 & 1.17 & 1.21 & 2.49 \\
\hline & \multicolumn{6}{|c|}{ Curitiba } \\
\hline Average & 2.67 & 3.48 & 2.42 & 3.46 & 2.50 & 1.06 \\
\hline Linear coefficient & & -0.28 & 0.65 & 0.53 & 0.66 & 1.62 \\
\hline Angular coefficient & & 0.85 & 0.84 & 0.62 & 0.81 & 1.09 \\
\hline $\mathrm{R}^{2}$ & & 0.40 & 0.59 & 0.57 & 0.38 & 0.59 \\
\hline $\mathrm{r}$ & & 0.64 & 0.77 & 0.75 & 0.61 & 0.77 \\
\hline Index "d" & & 0.88 & 0.63 & 0.62 & 0.55 & 0.48 \\
\hline Index "c" & & 0.56 & 0.49 & 0.47 & 0.33 & 0.37 \\
\hline Performance & & Tolerable & $\mathrm{Bad}$ & $\mathrm{Bad}$ & Very bad & Very bad \\
\hline \multirow[t]{2}{*}{ RMSE } & & 1.16 & 0.73 & 1.16 & 0.87 & 1.85 \\
\hline & \multicolumn{6}{|c|}{ Irati } \\
\hline Average & 2.30 & 3.46 & 2.43 & 3.60 & 2.45 & 1.09 \\
\hline Linear coefficient & & -0.47 & 0.58 & 0.02 & -0.21 & 1.56 \\
\hline Angular coefficient & & 0.93 & 0.89 & 0.75 & 1.17 & 1.22 \\
\hline $\mathrm{R}^{2}$ & & 0.38 & 0.53 & 0.70 & 0.63 & 0.58 \\
\hline $\mathrm{r}$ & & 0.61 & 0.73 & 0.84 & 0.79 & 0.76 \\
\hline Index “d" & & 0.87 & 0.72 & 0.77 & 0.66 & 0.55 \\
\hline Index "c" & & 0.53 & 0.52 & 0.64 & 0.52 & 0.42 \\
\hline Performance & & Tolerable & Tolerable & Median & Tolerable & $\mathrm{Bad}$ \\
\hline \multirow[t]{2}{*}{ RMSE } & & 1.21 & 0.90 & 1.15 & 0.75 & 1.96 \\
\hline & \multicolumn{6}{|c|}{ Ivaí } \\
\hline Average & 3.12 & 3.65 & 2.55 & 3.82 & 2.60 & 1.27 \\
\hline Linear coefficient & & -0.52 & 0.76 & 0.06 & 0.16 & 1.93 \\
\hline Angular coefficient & & 1.00 & 0.93 & 0.81 & 1.15 & 1.07 \\
\hline $\mathrm{R}^{2}$ & & 0.37 & 0.51 & 0.71 & 0.51 & 0.52 \\
\hline $\mathrm{r}$ & & 0.61 & 0.71 & 0.84 & 0.71 & 0.72 \\
\hline Index "d" & & 0.74 & 0.71 & 0.78 & 0.64 & 0.56 \\
\hline Index “c” & & 0.45 & 0.51 & 0.66 & 0.46 & 0.40 \\
\hline Performance & & $\mathrm{Bad}$ & Tolerable & Good & $\mathrm{Bad}$ & Very bad \\
\hline RMSE & & 1.17 & 1.10 & 1.02 & 1.09 & 2.21 \\
\hline
\end{tabular}

(1)Data from 1986 to 2015. 
climatic variables, agreeing with the results observed here for the climate types of Paraná. Souza et al. (2014) also agree that the use of solar radiation in alternative methods results in consistent estimates of ETo, for both hot and dry climates, and cold and humid climates. However, Gardiman Junior et al. (2012) considered that methods that use it are more appropriate to hot and dry climates.

According to Souza et al. (2014), the HargreavesSamani method tends to perform better in hot climate regions, with high average temperatures throughout the year, since the method is based on the mean temperature and on the maximum daytime temperature.

The Linacre method showed a good performance only in Campo Mourão (Cfa climate); and its performance in the other evaluated regions ranged between "poor" and "tolerable". This method was developed from data obtained in different locations of Africa and South America (Souza et al., 2014), and it is mostly a simplification of the Penman (1948) model, which uses air temperature functions as the difference between the mean temperature and the dew point temperature.

The methods of Thornthwaite and Budyko were not adequate to estimate ETo in neither of the climate types studied in Paraná. This result was due to the fact that they are based only on the air temperature. Mendonça et al. (2003), Cavalcante Júnior et al. (2011) and Todorovic et al. (2013) observed a better adjustment of these methods for hot and dry climates, which is in accordance with their low performances in the cold and humid climates of the state of Paraná.

\section{Conclusions}

1. The Hargreaves-Samani method performs better in estimating the reference evapotranspiration (ETo) for the main climate types of the state of Paraná, Brazil.

2. The Camargo method allows smaller errors between the standard values of ETo, obtained with Penman-Monteith, and estimated values.

3. The Thornthwaite, Linacre, and Budyko methods are not suited to estimate the ETo in neither of the climate types evaluated in the state of Paraná.

\section{Acknowledgments}

To Coordenação de Aperfeiçoamento de Pessoal de Nível Superior (Capes), for scholarship granted.

\section{References}

ALENCAR, L.P. de; SEDIYAMA, G.C.; MANTOVANI, E.C. Estimativa da evapotranspiração de referência (ETo padrão FAO), para Minas Gerais, na ausência de alguns dados . Engenharia Agrícola, v.35, p.39-50, 2015. DOI: 10.1590/1809-4430-Eng. Agric.v35n1p39-50/2015.

ALLEN, R.G.; PEREIRA, L.S.; RAES, D.; SMITH, M. Crop evapotranspiration: guidelines for computing crop water requirements. Rome: FAO, 1998. 300p. (FAO. Irrigation and Drainage Paper, n. 56).

ALLEN, R.G.; WALTER, I.A.; ELLIOTT, R.; HOWELL, R.; ITENFISU, D.; JENSEN, M. (Ed.). The ASCE standardized reference evapotranspiration equation: [S.1.]: ASCE-EWRI, 2005. 171p. Report of the Task Committee on Standardization of Reference Evapotranspiration: Environmental and Water Resources Institute of the American Society of Civil Engineers.

ALVARES, C. A.; STAPE, J.L.; SENTELHAS, P.J.; GONÇALVES, J.L.M.; SPAROVEK, G. Koppen's climate classification map for Brazil. Meteorologische Zeitschrift, v.22, p.711-728, 2013. DOI: 10.1127/0941-2948/2013/0507.

BORGES, A.C.; MENDIONDO, E.M. Comparação entre equações empíricas para estimativa da evapotranspiração de referência na Bacia do Rio Jacupiranga. Revista Brasileira de Engenharia Agrícola e Ambiental, v.11, p.293-300, 2007. DOI: 10.1590/S1415-43662007000300008.

BUDYKO, M. I. Climate and life. New York: Academic Press, 1974.

CAMARGO, A.P. Balanço hídrico no estado de São Paulo. Campinas: IAC, 1971. 28p.

CAMARGO, A.P. de; SENTELHAS, P.C. Avaliação do desempenho de diferentes métodos de estimativa da evapotranspiração potencial no Estado de São Paulo, Brasil. Revista Brasileira de Agrometeorologia, v.5, p.89-97, 1997.

CAMPBELL, A.P. The effect of stability on evaporation rates measured by the energy balance method. Agricultural Meteorology, v.11, p.261-267, 1973. DOI: 10.1016/00021571(73)90068-X.

CAVALCANTE JUNIOR, E.G.; OLIVEIRA, A.D.; ALMEIDA, B.M. de; ESPÍNDOLA SOBRINHO, J. Métodos de estimativa da evapotranspiração de referência para as condições do semiárido Nordestino. Semina: Ciências Agrárias, v.32, p.1699-1708, 2011. Suplemento 1. DOI: 10.5433/1679-0359.2011v32Suplp1699.

CHAUHAN, S.; SHRIVASTAVA, R.K. Performance evaluation of reference evapotranspiration estimation using climate based methods and artificial neural networks. Water Resources Management, v.23, p.825-837, 2009. DOI: 10.1007/s11269-0089301-5.

GARDIMAN JUNIOR, BS.; MAGALHÃES, I.A.L.; CECILIO, R.A. Comparação entre diferentes métodos de estimativa de evapotranspiração de referência (ETo) para Linhares-ES. Nucleus, v.9, p.103-112, 2012.

HARGREAVES, G.H.; SAMANI, Z.A. Reference crop evapotranspiration from temperature. Applied Engineering Agriculture, v.1, p.96-99, 1985. DOI: 10.13031/2013.26773. 
HIJMANS, R.J.; CAMERON, S.E.; PARRA, J.L.; JONES, P.G.; JARVIS, A. Very high resolution interpolated climate surfaces for global land areas. International Journal of Climatology, v.25, p.1965-1978, 2005. DOI: 10.1002/joc.1276.

HUPET, F.; VANCLOOSTER, M. Effect of the sampling frequency of meteorological variables on the estimation of the reference evapotranspiration. Journal of Hydrology, v.243, p.192-204, 2001. DOI: 10.1016/S0022-1694(00)00413-3.

INMET. Instituto Nacional de Meteorologia. BDMEP - Banco de dados meteorológicos para ensino e pesquisa. 2016. Available at: <http://www.bdmpe.inmet.br/>. Accessed on: Jun. 222016.

IRMAK, S.; PAYERO, J.O.; MARTIN, D.L.; IRMAK, A.; HOWELL, T.A. Sensitivity analyses and sensitivity coefficients of standardized daily ASCE-Penman-Monteith equation. Journal of Irrigation and Drainage Engineering, v.132, p.564-578, 2006. DOI: 10.1061/(ASCE)0733-9437(2006)132:6(564).

KÖPPEN, W. Das geographische System der Klimate. In: KÖPPEN, W.; GEIGER, R. (Ed.). Handbuch der Klimatologie. [Berlin]: Gebruder Borntrager, 1936. v.1, p.1-44.

LINACRE, E.T. A simple formula for estimating evapotranspiration rates in various climates, using temperature data alone. Agricultural Meteorology, v.18, p.409-424, 1977. DOI: 10.1016/0002-1571(77)90007-3.

MENDONÇA, J.C.; SOUSA, E.F. de; BERNARDO, S.; DIAS, G.P.; GRIPPA, S. Comparação entre métodos de estimativa da evapotranspiração de referência (ETo) na região Norte Fluminense, RJ. Revista Brasileira de Engenharia Agrícola e Ambiental, v.7, p.276-279, 2003. DOI: 10.1590/S1415-43662003000200015.

OLIVEIRA, R.A.; TAGLIAFERRE, C.; SEDIYAMA, G.C.; MATERAM, F.J.V.; CECON, P.R. Desempenho do irrigâmetro na estimativa da evapotranspiração de referência. Revista Brasileira de Engenharia Agrícola e Ambiental, v.12, p.166173, 2008. DOI: 10.1590/S1415-43662008000200009.

PANDEY, K.P.; DABRAL, P.P.; PANDEY, V. Evaluation of reference evapotranspiration methods for the northeastern region of India. International Soil and Water Conservation Research, v.4, p.52-63, 2016. DOI: 10.1016/j.iswcr.2016.02.003.

PENMAN, H.L. Natural evaporation from open water, bare soil and grass. Proceedings of the Royal Society, v.193, p.120-145, 1948. DOI: $10.1098 /$ rspa.1948.0037.

PEREIRA, A.R.; VILLA NOVA, N.A.; SEDYAMA, G.C. Evapo(transpi)ração. Piracicaba: ESALQ, 1997. 183p.
PEREIRA, L.S.; ALLEN, R.G.; SMITH, M.; RAES, D. Crop evapotranspiration estimation with FAO56: past and future. Agricultural Water Management, v.147, p.4-20, 2015. DOI: 10.1016/j.agwat.2014.07.031.

SOUZA, J.M. de; PEREIRA, L.R.; RAFAEL, A. da M.; SILVA, L.D. da; REIS, E.F. dos; BONOMO, R. Comparison of methods for estimating reference evapotranspiration in two locations of Espirito Santo. Revista Brasileira de Agricultura Irrigada, v.8, p.114-126, 2014. DOI: 10.12702/ii.inovagri.2014-a234.

SYPERRECK, V.L.G.; KLOSOWSKI, E.S.; GRECO, M.; FURLANETTO, C. Avaliação de desempenho de modelos para estimativas de evapotranspiração de referência para a região de Palotina, Estado do Paraná. Acta Scientiarum. Agronomy, v.30, p.603-609, 2008. Suplemento. DOI: 10.4025/actasciagron. v30i5.5959.

THORNTHWAITE, C.W. An approach toward a rational classification of climate. Geographical Review, v.38, p.55-94, 1948. DOI: $10.2307 / 210739$.

TODOROVIC, M.; KARIC, B.; PEREIRA, L.S. Reference evapotranspiration estimate with limited weather data across a range of Mediterranean climates. Journal of Hydrology, v. 481, p.166-176, 2013. DOI: 10.1016/j.jhydrol.2012.12.034.

TRAJKOVIC, S.; KOLAKOVIC, S. Evaluation of reference evapotranspiration equations under humid conditions. Water Resources Management, v.23, p.3057-3067, 2009. DOI: 10.1007/ s11269-009-9423-4.

WILLMOTT, C. J.; ROWE, C. M.; MINTZ, Y. Climatology of terrestrial seasonal water cycle. Journal of Climatology, v.5, p.589-606, 1985. DOI: 10.1002/joc.3370050602.

YAN, H.; WANG, S.Q.; BILLESBACH, D.; OECHEL, W.; ZHANG, J.H.; MEYERS, T.; MARTINS, T.A.; MATAMALA, R.; BALDOCCHI, D.; BOHRER, G.; DRAGONI, D.; SCOTT, R. Global estimation of evapotranspiration using a leaf area index-based surface energy and water balance model. Remote Sensing of Environment, v.124, p.581-595, 2012. DOI: 10.1016/j. rse.2012.06.004.

YODER, R.E.; ODHIAMBO, L.O.; WRIGHT, W.C. Evaluation of methods for estimating daily reference crop evapotranspiration at a site in the humid southeast United States. Applied Engineering in Agriculture, v.21, p.197-202, 2005. DOI: 10.13031/2013.18153.

Received on April 13, 2017 and accepted on December 11, 2017

Pesq. agropec. bras., Brasília, v.53, n.9, p.1003-1010, Sept. 2018

DOI: 10.1590/S0100-204X2018000900003 